\title{
Assay of Antibacterial and Antifungal Activity of Silver Nanoparticles Accompanying Different Impurities
}

\author{
Mohsen A. Sayed
}

Cairo University

Asmaa A. H. El-Bassuony ( $\square$ asmaa@sci.cu.edu.eg )

Cairo University https://orcid.org/0000-0003-0201-7538

\section{H. K. Abdelsalam}

Higher Institute of Applied Arts 5th Settlement

\section{Research Article}

Keywords: Novel, Silver nanoparticles, fungi, bacteria, MIC, resistance.

Posted Date: May 24th, 2021

DOI: https://doi.org/10.21203/rs.3.rs-392550/v1

License: (c) (i) This work is licensed under a Creative Commons Attribution 4.0 International License. Read Full License 


\section{Abstract}

No doubt that antimicrobial compounds such as antibiotics are the basic tools in clinical medicine. Increase in antimicrobial resistance may cause several human diseases. The potential of drugs and other agents can be improved by using nanoparticles. Wide use of antimicrobial compounds resulted in formation of resistance in microbes. There is demand to look for novel agents for therapy. Novel silver nanoparticles accompanied different impurities were assayed against Streptococcus pyogenes and Staphylococcus aureus (Gram-positive bacteria), Pseudomonas aeruginosa and Proteus mirabilis (Gramnegative bacteria). In addition to Aspergillus niger, A. terrus, Penicillium cluclauni and Rhizopus stolonofer fungi. Four Candida spp. were also assayed: $C$. krusei, $C$. famata, $C$. parapsilosis and $C$. utiliz. The method which applied in assaying these microorganisms was diffusion method. Dilution method was obtained for the tested nanoparticles to find the minimum inhibitory concentration MIC. The annealing temperature of the tested nanoparticles affected on antifungal and antibacterial activities. It was found that the preparation of nanoparticles at room temperature gave higher activities against tested antimicrobial than that at high temperatures.

\section{Key Points:}

The synthesized nanoparticles showed promising antimicrobial activity.

This article contains seven Tables and one Figure.

\section{Introduction}

Pathogenic bacteria that are antibiotic resistant cause great challenges in health worldwide (Mantravadi et al. 2019). Bacteria can resist old and newly discovered antibiotics through inherent and acquired mechanisms (Abusaiba and AL-Harmoosh 2020). Fluconazole was the primary therapeutic agent for treatment of fungal infections. Now it is only a fungistatic agent against Candida spp. where both inherent and acquired resistance has been reported (Berkow and Lockhart 2017). Resistance includes alteration in the target of the drug, increase in efflus of the drug, and presence of different pathways for target sterol production (Jarvis 1995). The spread of drug-resistant microorganisms represents huge challenges in healthcare worldwide (Sharafutdinov et al. 2020). It was reported that Aspergillus sp had the lowest antifungal activity in comparison to caspofungin and triazoles (Lalitha et al. 2007). Generally, the preparation of nanoparticles has a great effect on the antimicrobial study. There are two methods to prepare different nanoparticles materials, solid state and wet methods. In the solid-state method, bulk nanoparticles are prepared; while in the wet method, nanoparticles are prepared (Nadaroglu et al. 2017; El-Bassuony and Abdelsalam 2017, 2018 (1, 2, 3, 4), 2019 (1, 2), 2020 (1); El-Bassuony 2020 (1); Maklad et al. 2014). To synthesize novel antimicrobial drugs, researchers in nanotechnology and biological science should be cooperated to improve the drug efficacy. (Ventola 2015; Lu et al. 2017). Nanoparticles show simultaneous multiple mechanisms against the resistance of microbes (Singh et al. 2014; Cavassin et al. 2015). Such mechanisms include release of metal ions, oxidative stress, and non-oxidative stress. This makes resistance difficult to develop (Wang et al. 2017). Finally, silver nanoparticles are applied in different fields including antimicrobial activity, water purification, cancer treatment, magnetic targeting, and biomedical applications (Paula et al. 2009; Nangmenyi et al. 2011; Abdelhamid et al. 2015; El-Bassuony 2017, 2018 (1, 2), 2020 (2); Abdelsalam 2018; Ateia 2017; Sayed et al. 2020(1, 2)).

The novelty of this work is the assaying of silver nanoparticles accompanying different impurities against different opportunistic fungal and bacterial spp. It is reported from previous studies of silver nanoparticles accompanying different impurities showed fascinating physical properties that can be used as alternative drug nanomaterials (El-Bassuony and Abdelsalam $2020(2,3))$. Thus, the aim of the present work is based on the study of antimicrobial effect on a novel synthesized silver nanoparticle accompanied different impurities against opportunistic bacterial and fungal species.

\section{Materials And Methods}




\section{Synthesis of silver nanoparticles accompanied different impurities}

Silver nanoparticles were prepared flash method (an easy and low cost method). The materials used in the preparation were:

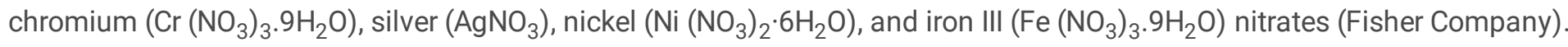
All materials were mixed in distilled water; urea was added drowsily. The mixture was heated to $250{ }^{\circ} \mathrm{C}$ till and the samples were collected to be ground for $0.5 \mathrm{~h}$. Finally, some samples were annealed at $400^{\circ} \mathrm{C}$ and were ground also for half an hour. Thus, the prepared samples were Ag nanoparticles accompanied iron oxide impurities a, $\mathrm{y}-\mathrm{Fe}_{2} \mathrm{O}_{3}(\mathrm{Ag}-\mathrm{Fe})$, Ag nanoparticles accompanied iron and nickel oxide impurities $\mathrm{a}, \mathrm{\gamma}-\mathrm{Fe}_{2} \mathrm{O}_{3}, \mathrm{NiO}$ (Ag-Fe-Ni), Ag nanoparticles accompanied delafossite and chromite (Ag-D-C), Ag nanoparticles accompanied delafossite (Ag-D) as-prepared and at $400^{\circ} \mathrm{C}$.

\section{Biological study}

\section{Materials}

Bacterial and fungal species were supplied via Microanalytical Center, Faculty of Science, Cairo University.

\section{Identification and growth of micro-organisms}

Fungi had grown on potato dextrose agar (PDA) media and incubated for seven days at $25^{\circ} \mathrm{C}$ (Adwic, El-Nasr chemical Co. Egypt). The fungal species were then identified based on some characters such as: shape of conidia/spores, colony shape, colony pigmentation and presence of septa (Moubasher 1993; Maadon et al. 2018; Raper and Fennell 1965). Bacteria had grown on nutrient agar and blood agar plates. The colonies had been recognized biochemically and morphologically (Holt et al. 1994).

\section{Antimicrobial study of silver nanoparticles accompanied different impurities}

The antimicrobial activity of silver nanoparticles accompanied different impurities were tested against Aspergillus niger, $A$. terrus, Penicillium cluclauni and Rhizopus stolonofer fungal species. Also, the nanoparticles were tested against Candia spp.: C. famata, $C$. parapsilosis, $C$. krusei and $C$. utiliz, fungal species. The tested fungi were added to fresh PDA media before solidification at concentration $10^{6}$ colony forming unit/ml (CFU/ml). Then, $100 \mathrm{mg} / \mathrm{ml}$ of the investigated nanoparticles was added into the surface of agar plates which were incubated for 5 days at $27^{\circ} \mathrm{C}$. The standard antifungal drug which used in the present work is $100 \mathrm{mg} / \mathrm{ml}$ of Fluconazole however $100 \mathrm{mg} / \mathrm{ml}$ of Ampicillin was used as a control (Saadabi et al. 2012). The tested bacteria Staphylococcus aureus and Streptococcus pyogenes (Gram positive bacteria), Proteus mirabilis and Pseudomonas aeruginosa (Gram-negative bacteria), were added at concentration $10^{6}$ (CFU/ml) before solidification. Then, $100 \mathrm{mg} / \mathrm{ml}$ of silver nanoparticles accompanied different impurities was added into the surface of the agar plates which were incubated for 2 days at $35^{\circ} \mathrm{C}$.

\section{Estimation of minimum inhibitory concentration}

MIC (minimum inhibitory concentration) was determined by Pershin method (Pershin 1971). The inhibitory effect of minimum concentration of silver nanoparticles accompanied different impurities on bacterial and fungal growth was obtained by Serial Dilution method using bifold dilution concentrations from $6.25,12.5,25,50$, and $100 \mathrm{mg} / \mathrm{ml}$. The dimethyl sulfoxide (DMSO) solvent was used to dissolve the tested nanoparticles. The culture media for bacteria is Mueller-Hinton broth liquid medium however that for fungi is and Sabouraud liquid media. For bacteria the test inoculums are $5 \times 10^{4} \mathrm{CFU} / \mathrm{ml}$ bacteria per $\mathrm{ml}$ however for fungi the test inoculums are $10^{3} \mathrm{CFU} / \mathrm{ml}$ fungal spores per $\mathrm{ml}$. Then, the tested compounds were added onto agar surface after inoculation with the test organism with incubation of plates at $30^{\circ} \mathrm{C}$. Finally, the lowest concentration that showed no growth (MIC) was obtained after incubation o 2- 7 days.

\section{Statistical analysis}


Statistical analysis was obtained using SPSS (Statistical Package of the Social Sciences) version 22. The homogeneity of different treatments was examined using Duncan's test. The significant results were at $P<0.05$, whereas the insignificant results were at $P>0.05$. The reported data is (mean \pm standard deviation (SD)) (Tahir et al. 2009; Duncan 1955; Maadon et al. 2018; Holt et al. 1994).

\section{Results}

\section{Assay of synthesized silver nanoparticles accompanied different impurities against fungal species}

Tables 1 \& 2 showed the highest antifungal effect against tested fungal species while Tables 4 \& 5 showed the lowest MIC values for Ag-D-C and Ag-D synthesized at 30 and $400{ }^{\circ} \mathrm{C}$ in comparison with the other tested nanosamples that gave lesser antifungal activity and higher MIC values.

\section{Assay of synthesized silver nanoparticles accompanied different impurities against bacterial species}

One can obtain from the results of antibacterial activity, that the sensitivity of Gram-positive bacteria to the investigated samples was greater than that of Gram-negative bacteria. Table 3 showed that Ag-Fe, followed by Ag-D and Ag-D-C, showed the highest antibacterial effect against the tested bacterial species and the lowest MIC values with respect to the remaining tested nanosamples that showed lesser antibacterial activity and high MIC values as shown in Table 6.

\section{Structural properties}

It is reported from previous studies in details the physical and magnetic properties of silver nanoparticles accompanied by different impurities (El-Bassuony AAH, Abdelsalam HK 2020(2, 3)). Table 7 showed the crystallite size and the particle size estimated from X-ray diffraction pattern (XRD), field emission scanning electron microscopy (FESEM) and atomic force microscopy (AFM). These analyses emphasize the nanosize of the investigated samples. Moreover, the crystallite size increased by increasing the annealing temperature as shown from Table (7).

\section{Discussion}

The great demand from many researchers to find novel drugs to overcome the microbial resistance problem that caused health problems all over the world (El-Bassuony and Abdelsalam 2018 (1, 2); Abusaiba and AL-Harmoosh 2020; Berkow and Lockhart 2017). Silver nanoparticles compounds have various applications in many fields especially in biomedical field. The antimicrobial activities were studied for many nanoparticles such as titanium dioxide (Panáček et al. 2009; Gutierrez et al. 2010), zinc oxide (Wani and Shah 2012), magnesium oxide (Kanhed et al. 2014), and copper (Ezema et al. 2010). Nanoparticles can be prepared by many methods however flash technique gave very fine nanoparticles and low cost method which was chosen in preparation of the investigated samples. The annealing temperature is an important parameter that affect the particle size of the nanosamples. Thus, the more efficient annealing temperature is low temperature that gives fine nanoparticles which could be able to penetrate the membrane of the microbial cell and destroy the internal molecules causing the death of the microbes (Hafiz et al. 2015; Mallika et al. 2015; Talal and Ali 2015; Bharamagoudar et al. 2018). The inhibition zone diameter increased by increasing the concentration of the investigated samples. One can obtain that the investigated samples had an effect against antibacterial activities (Gram positive and Gram negative). Moreover, when adding the investigated samples to the tested microbes caused DNA, protein and lipid damage and caused a death to the microbes (Clinical and Laboratory Standards Institute 2013). Thus, authors strongly recommended to use the investigated samples as an alternative antibiotic.

There is another publication to study cytotoxicity assay with concentrations $6.25,12.5,25,50$, and $100 \mathrm{mg} / \mathrm{ml}$. Furthermore, it is required to study the investigated samples in vivo using animal models to study the treatment of fungal and bacterial infections. 
To summarize, in the present study, novel silver nanoparticles accompanied different impurities were synthesized and showed that Ag-D and Ag-D-C had high in vitro antifungal effect, while Ag-Fe was the most powerful compound against bacteria. The best activities was shown for compounds that synthesized at $30^{\circ} \mathrm{C}$. Finally, Ag-D, Ag-D-C and Ag-Fe are promising compounds that could be used as an alternative drug in the future.

\section{Declarations}

\section{Authors' contributions}

MAS and AAH conceived and designed research. MAS and HAK conducted experiments. AAH contributed new reagents. AAH and HAK analyzed data. MAS and AAH wrote the manuscript. All authors read and approved the manuscript.

\section{Compliance with ethical standards}

This article does not contain any studies with human participants or animals performed by the authors.

\section{Conflict of interest}

The authors declare that they have no conflict of interest.

\section{Compliance with Ethical Standards}

This article does not contain any studies with human participants or animals performed by any of the authors.

\section{Data availability}

The datasets generated during and/or analysed during the current study are available from the corresponding author on reasonable request.

\section{References}

1. Abdelhamid HN, Talib A, Wu H-F (2015) Facile synthesis of water-soluble silver ferrite (AgFeO2) nanoparticles and their biological application as antibacterial agents. RSC Adv 5:

34594-34602.

2. Abdelsalam HK (2018) Enhancing the structural and spectroscopic properties of $\mathrm{Cr} 3+$ ion-doped Ni/Cd/Zn nanoferrite to be applied to industrial applications. J Supercond Nov Magn 31:4063-4077. https://doi.org/10.1007/s10948-018-46895

3. Abusaiba THH, AL-Harmoosh R (2020) Genotypic Characterization of Antimicrobial Resistance- Associated Genes in Citrobacter Freundii Isolated from Patients with Urinary Tract Infection in Al-Najaf Governorate-Iraq. Systematic Reviews in Pharmacy 11(6):817-823

4. Ateia $\mathrm{E}$, El-Bassuony AAH (2017) Fascinating improvement in physical properties of $\mathrm{Cd} / \mathrm{Co}$ nanoferrites using different rare earth ions. J Mater Sci: Mater Electron 28:11482-11490. https://doi.org/10.1007/s10854-017-6944-0

5. Berkow E, Lockhart SR (2017) Fluconazole resistance in Candida species: a current perspective. Infect Drug Resist 10:237-245

6. Bharamagoudar RC, Patil AS, Vijay SNM, Laxmi MK, Kankanawadi B (2018) Magnetic and antibacterial studies of nanoferrites prepared by self-propagating high-temperature synthesis route. Acta Chemica IASI 26(2):249-262

7. Cavassin ED, de Figueiredo LF, Otoch JP, Seckler MM, de Oliveira RA, Franco FF, Marangoni V, Zucolloto V, Levin ASS, Costa SF (2015) Comparison of methods to detect the in vitro activity of silver nanoparticles (AgNP) against multidrug resistant bacteria. J Nanobiotech 13(1):64 
8. Clinical and Laboratory Standards Institute (2013) Performance standards for antimicrobial susceptibility testing; twentythird informational supplement CLSI document M100-S23. CLSI, Wayne

9. Duncan DB (1955) Multiple range and multiple. F-test Biom 11(1):1-42

10. El-Bassuony AAH (2017) Enhancement of structural and electrical properties of novelty nanoferrite materials. J Mater Sci: Mater Electron 28:14489-14498. https://doi.org/10.1007/s10854-017-7312-9

11. El-Bassuony AAH (2018(1)) Tuning the structural and magnetic properties on $\mathrm{Cu} / \mathrm{Cr}$ nanoferrite using different rare-earth ions. J Mater Sci: Mater Electron 29:3259-3269. https://doi.org/10.1007/s10854-017-8261-z

12. El-Bassuony AAH (2018(2)) A comparative study of physical properties of Er and $\mathrm{Yb}$ nanophase ferrite for industrial application. J Supercond Nov Magn 31:2829-2840. https://doi.org/10.1007/s10948-017-4543-1

13. El-Bassuony AAH (2020(1)) Effect of Al addition on structural, magnetic, and antimicrobial properties of Ag nanoparticles for biomedical applications. JOM 72: 1154-1162. https://doi.org/10.1007/s11837-019-03784-2

14. El-Bassuony AAH (2020(2)) Influence of high annealing temperature on structural, magnetic and antimicrobial activity of silver chromite nanoparticles for biomedical applications. J Inorg Organomet Polym 30: 1821-1828. https://doi.org/10.1007/s10904-019-01306-w

15. El-Bassuony $\mathrm{AAH}$, Abdelsalam HK (2017) Modification of $\mathrm{AgFeO}_{2}$ by double nanometric delafossite to be suitable as energy storage in solar cell. J Alloys Compd 726:1106-1118. https://doi.org/10.1016/j.jallcom.2017.08.087

16. El-Bassuony AAH, Abdelsalam HK (2018(1)) Synthesis, characterization and antimicrobial activity of $\mathrm{AgFeO}_{2}$ delafossite. J Mater Sci: Mater Electron 29:11699-11711. https://doi.org/10.1007/s10854-018-9268-9

17. El-Bassuony AAH, Abdelsalam HK (2018) Attractive improvement in structural, magnetic, optical, and antimicrobial activity of silver delafossite by Fe/Cr doping. J Supercond Nov Magn 31(2):3691-3703. https://doi.org/10.1007/s10948018-4627-6

18. El-Bassuony AAH, Abdelsalam HK (2018(3)) Giant exchange bias of hysteresis loops on $\mathrm{Cr}^{3+}$-doped Ag nanoparticles. J Supercond Nov Magn 31:1539-1544. https://doi.org/10.1007/s10948-017-4340-x

19. El-Bassuony AAH, Abdelsalam HK (2018(4)) Enhancement of AgCrO2 by double nanometric delafossite to be applied in many technological applications. J Mater Sci: Mater Electron 29:5401-5412. https://doi.org/10.1007/s10854-017-8506$x$

20. El-Bassuony AAH, Abdelsalam HK (2019(1)) Tailoring the structural, magnetic and antimicrobial activity of $\mathrm{AgCrO} 2$ delafossite via high annealing temperature. J Therm Anal Calorim. 138: 81-88. https://doi.org/10.1007/s10973-01908207-7

21. El-Bassuony AAH, Abdelsalam HK (2019(2)) Fascinating study of the physical properties of a novel nanometric delafossite for biomedical applications JOM 71: 1866-1873. https://doi.org/10.1007/s11837-019-03415-w

22. El-Bassuony AAH, Abdelsalam HK (2020(1)) Synthesis, characterization, magnetic and antimicrobial properties of silver chromite nanoparticles. J Mater Sci: Mater Electron 31: 3662-3673. https://doi.org/10.1007/s10854-020-02924-8

23. El-Bassuony AAH, Abdelsalam HK (2020(2)) Impacts of hematite, Bunsenite and maghemite impurities on the physical and antimicrobial properties of silver nanoparticles. Eur Phys J Plus 35: 64.

24. El-Bassuony AAH, Abdelsalam HK (2020(3)) Correlation of heat treatment and the impurities accompanying Ag nanoparticles. Eur Phys J Plus 135:66. https://doi.org/10.1140/epjp/s13360-019-00025-y

25. Ezema Fl, Nwankwo UOA (2010) Effect of annealing temperature on the the structural and optical properties of zinc oxide (ZnO) nanocrystals prepared by sol gel. Digest J Nanomater Biostruct 5(4):981-988.

26. Gutierrez FM, Olive PL, Banuelos A, Orrantia E, Nino N, Sanchez EM, Ruiz F, Bach H,Av-Gay Y (2010) Nanomed Nanotechnol Biol Med 6:681.

27. Hafiz MM, El-Kabany N, Kotb HM, Bakier YM (2015) Annealing effects on structural and optical properties of Ge10Sb30Se60 thin film. Int J Thin Fil Sci Tec 4(3):163-171. 
28. Holt JG, Krieg NR, Sneath PHA, Staley JT, Williams ST (1994) Genus Acetobacter and Gluconobacter. Bergey's manual of determinative bacteriology. 9th edn. Williams and Wilkens, MD USA 14:668-675.

29. Jarvis WR (1995) Epidemiology of nosocomial fungal infections, with emphasis on Candida species. Clin Infect Dis. 20(6):1526-1530.

30. Kanhed P, Birla S, Gaikwad S, Gade A, Seabra AB, Rubilar O, Duran N, Rai M (2014)In vitro antifungal efficacy of copper nanoparticles against selected crop pathogenic fungi. Mater Lett 115:13-17.

31. Lalitha P, Shapiro B, Srinivasan M, Prajna NV, Acharya NR, Fothergill AW, Ruiz J,Chidambaram JD, Maxey KJ, Hong KC, McLeod S, Lietman TM (2007) Antimicrobial susceptibility of Fusarium, Aspergillus, and other filamentous fungi isolated from keratitis. Arch Ophthalmol 125(6):789-793

32. Lu HD, Yang SS, Wilson BK, McManus Chen CV (2017) Nanoparticles targeting of Gram-positive and Gram-negative bacteria for magnetic-based separations of bacterial pathogens.Appl Nanosci 7(3):83-93.

33. Maadon SN, Wakid SA, Zainudin II, Rusli LS, Mohdzan MS, Hasan N, NOR'AISHAH Abushah N \& Rohani ER. (2018) Isolation and identification of endophytic fungi from UiTM Reserve Forest, Negeri Sembilan. Sains Malaysiana 47(12): 3025-3030.

34. Maklad MH, Shash NM, Abdelsalam HK (2014) Structural and magnetic properties of nanograined Ni0.7 - y Zn0.3 CayFe2O4 spinels. Eur Phys J Appl Phys 66:30402. https://doi.org/10.1051/epjap/2014130573.

35. Mallika AN, Ramachandra A, Reddy K, Reddy V (2015) Annealing effects on the structural and optical properties of ZnO nanoparticles with PVA and CA as chelating agents. J Adv Ceramics, Eramics 4(2):123-129.

36. Mantravadi PM, Kalesh KA, Dobson RCJ, Hudson AO and Parthasarathy A (2019) The Quest for Novel Antimicrobial Compounds: Emerging Trends in Research, Development, and Technologies,Antibiotics 8: 8.

37. Moubasher AH (1993) Soil fungi in Qatar and other Arab countries. In: The Scientific and Applied Research Center. University of Qatar, Doha.

38. Nadaroglu H, Alayli GA, Ince S (2017) Synthesis of nanoparticles by green synthesis method. Int J Innov Res Rev 1:6-9.

39. Nangmenyi G, Li X, Mehrabi S, Mintz E, Economy J (2011) Silver modified iron oxide nanoparticle impregnated fiberglass for disinfection of bacteria and viruses in water.Mater Lett 65:1191-1193.

40. Paula MM, Franco CV, Cesar BM, Rodrigues L, Barichello T, Savi GD, Bellato LF, Fiori MA, Silva LD (2009) Synthesis, characterization and antibacterial activity studies of poly-\{styrene-acrylic acid\} with silver nanoparticles. Mater Sci Eng 29:647-650.

41. Panác ``ek A, Kolár` M, Vec er`ová R, Prucek R, Soukupová J, Kryštof V, Hamal P, Zbor`il R, Kvítek L (2009) Antifungal activity of silver nanoparticles against Candida spp. Biomaterials 30:6333-6340.

42. Pershin GN (1971) Methods of the experimental chemotherapy. Meditsina, Moskwa, p 103.

43. Raper KB, Fennell PI (1965) The genus Aspergillus. Williama and Wlkins, Baltimore, pp 33-111

44. Saadabi AMA, Ali NM, Mohammed HI, Alsafi FN, Mustafa HB (2012) An in vitro antimicrobial activity of Calotropis procera (Ait). R Br extracts on certain groups of pathogenic microorganisms. Res J Med Sci 6(1):13-17.

45. Sayed MA, Abdelsalam HK, El-Bassuony AAH (2020(1)) Antimicrobial activity of novel spinel nanoferrites against pathogenic fungi and bacteria. World J Microbiol Biotechnol 36:25. https://doi.org/10.1007/s11274-020-2803-x

46. Sayed MA, El-Bassuony AAH, Abdelsalam HK, Evaluation of antimicrobial properties of a Novel synthesized nanometric Delafossite, Braz J Microbiol (2020(2)). https://doi.org/10.1007/s42770-020-00366-2

47. Sharafutdinov IS, Ozhegov GD, Sabirova AE, Novikova VV, Lisovskaya SA, Khabibrakhmanova AM, Kurbangalieva AR, Kurbangalieva AR, Bogachev MI, Kayumov AR (2020) Increasing susceptibility of drug resistant Candida albicans to fluconazole and terbinafine by 2(5H)-furanone derivative. Molecules 25:642. https://doi.org/10. 3390/molecules25030642

48. Singh R, Smitha MS, Singh SP (2014) The role of nanotechnology in combating multi-drug resistant bacteria. J Nanosci Nanotechnol 14(7):4745-4756. 
49. Talal S, Ali AF (2015) Effect of zinc oxide nanoparticles on Candida albicans of human saliva (in vitro study). Eur J Med 10(4):235-244.

50. Tahir D, Lee EK, Tham TT, Oh SK, Kang HJ, Hua J, Heo S, Park JC, Chung JG, Lee JC (2009) Band alignment of atomic layer deposited (ZrO2)x(SiO2)1-x gate dielectrics on Si (100). Appl

Phys Lett 94:212902.

51. Wani AH, Shah MA (2012) J Appl Pharm Sci 2:40.

52. Ventola CL (2015) The antibiotic resistance crisis. Part 1: causes and threats. Pharm Ther 40:277-283

53. Wang L, Hu C, Shao L (2017) The antimicrobial activity of nanoparticles: present situation and prospects for the future. Int J Nanomedicine 12:1227-1249.

\section{Tables}

Table 1

Antifungal activity of the synthesized silver nanoparticles accompanied different impurities against filamentous fungi

\begin{tabular}{|c|c|c|c|c|c|c|c|c|c|}
\hline \multirow[t]{2}{*}{ Compounds } & \multirow{2}{*}{$\begin{array}{l}\text { Temp. of } \\
\text { synthesis } \\
\text { QC }\end{array}$} & \multicolumn{2}{|c|}{ Aspergillus niger } & \multicolumn{2}{|l|}{ A. terrus } & \multicolumn{2}{|c|}{ Penicillium cluclauni } & \multicolumn{2}{|c|}{ Rhizopus stolonofer } \\
\hline & & $\begin{array}{l}\text { Inhibition } \\
\text { zone } \\
\text { diameter } \\
(\mathrm{mm})\end{array}$ & $\begin{array}{l}\text { Relative } \\
\text { activity } \\
\text { (\%) }\end{array}$ & $\begin{array}{l}\text { Inhibition } \\
\text { zone } \\
\text { diameter } \\
(\mathrm{mm})\end{array}$ & $\begin{array}{l}\text { Relative } \\
\text { activity } \\
\text { (\%) }\end{array}$ & $\begin{array}{l}\text { Inhibition } \\
\text { zone } \\
\text { diameter } \\
(\mathrm{mm})\end{array}$ & $\begin{array}{l}\text { Relative } \\
\text { activity } \\
\text { (\%) }\end{array}$ & $\begin{array}{l}\text { Inhibition } \\
\text { zone } \\
\text { diameter } \\
(\mathrm{mm})\end{array}$ & $\begin{array}{l}\text { Relative } \\
\text { activity } \\
\text { (\%) }\end{array}$ \\
\hline $\begin{array}{l}\text { Fluconazole } \\
\text { (control) }\end{array}$ & - & 20 & 100 & 18 & 100 & 19 & 100 & 22 & 100 \\
\hline Ag-D-C & 30 & 25 & 125 & 24 & 133.3 & 16 & 84.2 & 14 & 63.6 \\
\hline$A g-D$ & 400 & 20 & 100 & 22 & 122.2 & 18 & 94.7 & 17 & 77.3 \\
\hline $\mathrm{Ag}-\mathrm{Fe}$ & 30 & 13 & 65 & 16 & 88.9 & 14 & 73.7 & 14 & 63.6 \\
\hline $\mathrm{Ag}-\mathrm{Fe}$ & 400 & 3 & 15 & 0 & 0 & 2 & 10.5 & 0 & 0 \\
\hline $\mathrm{Ag}-\mathrm{Fe}-\mathrm{Ni}$ & 30 & 12 & 60 & 8 & 44.4 & 12 & 63.2 & 10 & 45.5 \\
\hline $\mathrm{Ag}-\mathrm{Fe}-\mathrm{Ni}$ & 400 & 3 & 15 & 0 & 0 & 2 & 10.5 & 0 & 0 \\
\hline
\end{tabular}

Data is represented as mean \pm standard deviation.

In the same raw, the values marked with the same superscript letter are similar $(P>0.05)$, whereas those marked with different ones are significantly different $(P<0.05)$. 
Table 2

Antifungal activity of the synthesized silver nanoparticles accompanied different impurities against Candida sp.

\begin{tabular}{|c|c|c|c|c|c|c|c|c|c|}
\hline \multirow[t]{2}{*}{ Compounds } & \multirow{2}{*}{$\begin{array}{l}\text { Temp. } \\
\text { of } \\
\text { synthesis } \\
\text { ØC }\end{array}$} & \multicolumn{2}{|c|}{ Candida famata } & \multicolumn{2}{|c|}{ C. parapsilosis } & \multicolumn{2}{|l|}{ C. krusei } & \multicolumn{2}{|l|}{ C. utiliz } \\
\hline & & $\begin{array}{l}\text { Inhibition } \\
\text { zone } \\
\text { diameter } \\
(\mathrm{mm})\end{array}$ & $\begin{array}{l}\text { Relative } \\
\text { activity } \\
\text { (\%) }\end{array}$ & $\begin{array}{l}\text { Inhibition } \\
\text { zone } \\
\text { diameter } \\
(\mathrm{mm})\end{array}$ & $\begin{array}{l}\text { Relative } \\
\text { activity } \\
\text { (\%) }\end{array}$ & $\begin{array}{l}\text { Inhibition } \\
\text { zone } \\
\text { diameter } \\
(\mathrm{mm})\end{array}$ & $\begin{array}{l}\text { Relative } \\
\text { activity } \\
\text { (\%) }\end{array}$ & $\begin{array}{l}\text { Inhibition } \\
\text { zone } \\
\text { diameter } \\
(\mathrm{mm})\end{array}$ & $\begin{array}{l}\text { Relative } \\
\text { activity } \\
\text { (\%) }\end{array}$ \\
\hline $\begin{array}{l}\text { Fluconazole } \\
\text { (control) }\end{array}$ & - & 22 & 100 & 20 & 100 & 20 & 100 & 18 & 100 \\
\hline Ag-D-C & 30 & 31 & 140.9 & 30 & 150 & 25 & 125 & 28 & 155.6 \\
\hline$A g-D$ & 400 & 23 & 104.5 & 20 & 100 & 21 & 105 & 21 & 116.7 \\
\hline $\mathrm{Ag}-\mathrm{Fe}$ & 30 & 14 & 63.6 & 10 & 50 & 10 & 50 & 12 & 66.7 \\
\hline $\mathrm{Ag}-\mathrm{Fe}$ & 400 & 5 & 22.7 & 0 & 0 & 0 & 0 & 3 & 16.7 \\
\hline $\mathrm{Ag}-\mathrm{Fe}-\mathrm{Ni}$ & 30 & 15 & 68.2 & 10 & 50 & 12 & 60 & 12 & 66.7 \\
\hline $\mathrm{Ag}-\mathrm{Fe}-\mathrm{Ni}$ & 400 & 6 & 27.3 & 4 & 20 & 0 & 0 & 2 & 11.1 \\
\hline \multicolumn{10}{|c|}{ Data is represented as mean \pm standard deviation. } \\
\hline $\begin{array}{l}\text { In the same } \\
\text { different one }\end{array}$ & the valu & arked wi & $\begin{array}{l}\text { he same } \\
P<0.05) \text {. }\end{array}$ & & & & & & \\
\hline
\end{tabular}

Table 3

Antibacterial activity of the synthesized silver nanoparticles accompanied different impurities against Gram + ve and Gram -

\begin{tabular}{|c|c|c|c|c|c|c|c|c|c|}
\hline \multirow[t]{3}{*}{ Compounds } & \multirow{3}{*}{$\begin{array}{l}\text { Temp. of } \\
\text { synthesis } \\
\text { QC }\end{array}$} & \multicolumn{4}{|c|}{ Gram + ve Bacteria } & \multicolumn{4}{|c|}{ Gram -ve Bacteria } \\
\hline & & \multicolumn{2}{|c|}{$\begin{array}{l}\text { Staphylococcus } \\
\text { aureus }\end{array}$} & \multicolumn{2}{|c|}{$\begin{array}{l}\text { Streptococcus } \\
\text { pyogenes }\end{array}$} & \multirow{2}{*}{$\begin{array}{l}\text { Proteus } \\
\text { mirabilis } \\
\text { Inhibition } \\
\text { zone } \\
\text { diameter } \\
(\mathrm{mm})\end{array}$} & \multicolumn{3}{|c|}{ Pseudomonas aeruginosa } \\
\hline & & $\begin{array}{l}\text { Inhibition } \\
\text { zone } \\
\text { diameter } \\
(\mathrm{mm})\end{array}$ & $\begin{array}{l}\text { Relative } \\
\text { activity } \\
\text { (\%) }\end{array}$ & $\begin{array}{l}\text { Inhibition } \\
\text { zone } \\
\text { diameter } \\
(\mathrm{mm})\end{array}$ & $\begin{array}{l}\text { Relative } \\
\text { activity } \\
(\%)\end{array}$ & & $\begin{array}{l}\text { Relative } \\
\text { activity } \\
\text { (\%) }\end{array}$ & $\begin{array}{l}\text { Inhibition } \\
\text { zone } \\
\text { diameter } \\
(\mathrm{mm})\end{array}$ & $\begin{array}{l}\text { Relative } \\
\text { activity } \\
(\%)\end{array}$ \\
\hline $\begin{array}{l}\text { Ampicillin } \\
\text { (control) }\end{array}$ & - & 30 & 100 & 31 & 100 & 27 & 100 & 28 & 100 \\
\hline Ag-D-C & 30 & 10 & 33.3 & 8 & 25.8 & 6 & 22.2 & 6 & 21.4 \\
\hline$A g-D$ & 400 & 0 & 0 & 0 & 0 & 0 & 0 & 0 & 0 \\
\hline $\mathrm{Ag}-\mathrm{Fe}$ & 30 & 40 & 133.3 & 38 & 122.6 & 27 & 100 & 30 & 107.1 \\
\hline $\mathrm{Ag}-\mathrm{Fe}$ & 400 & 0 & 0 & 0 & 0 & 0 & 0 & 0 & 0 \\
\hline $\mathrm{Ag}-\mathrm{Fe}-\mathrm{Ni}$ & 30 & 8 & 26.7 & 5 & 16.1 & 2 & 7.4 & 0 & 0 \\
\hline $\mathrm{Ag}-\mathrm{Fe}-\mathrm{Ni}$ & 400 & 2 & 6.7 & 3 & 9.7 & 0 & 0 & 0 & 0 \\
\hline \multicolumn{10}{|c|}{ Data is represented as mean \pm standard deviation. } \\
\hline
\end{tabular}


Table 4

Minimum inhibitory concentration (MIC mg/ml) of the synthesized silver nanoparticles accompanied different impurities against tested filamentous fungi

\begin{tabular}{|llllll|}
\hline Compounds & $\begin{array}{l}\text { Temp. of } \\
\text { synthesis }\end{array}$ & $\begin{array}{l}\text { Aspergillus } \\
\text { niger, }\end{array}$ & $\begin{array}{l}\text { A. } \\
\text { terrus, }\end{array}$ & $\begin{array}{l}\text { Penicillium } \\
\text { cluclauni }\end{array}$ & $\begin{array}{l}\text { Rhizopus } \\
\text { stolonofer }\end{array}$ \\
\hline $\begin{array}{l}\text { Fluconazole } \\
\text { (Control) }\end{array}$ & - & 25 & 25 & 25 & 25 \\
\hline Ag-D-C & 30 & 12.5 & 12.5 & 50 & 50 \\
\hline Ag-D & 400 & 25 & 25 & 50 & 50 \\
\hline Ag-Fe & 30 & 50 & 50 & 50 & 50 \\
\hline Ag-Fe & 400 & $>100$ & $>100$ & $>100$ & $>100$ \\
\hline Ag-Fe-Ni & 30 & $>100$ & $>100$ & $>100$ & $>100$ \\
\hline Ag-Fe-Ni & 400 & $>100$ & $>100$ & $>100$ & $>100$ \\
\hline
\end{tabular}

Table 5

Minimum inhibitory concentration (MIC) of the synthesized silver nanoparticles accompanied different impurities against tested Candida sp.

\begin{tabular}{|llllll|}
\hline Compounds & \multicolumn{1}{l}{ Temp. of synthesis } & Candida famata & C. parapsilosis & C. krusei & C. utiliz \\
& $\otimes$ C & & & & \\
\hline Fluconazole (Control) & - & 50 & 50 & 50 & 50 \\
\hline Ag-D-C & 30 & 25 & 25 & 50 & 25 \\
\hline Ag-D & 400 & 50 & 50 & 50 & 50 \\
\hline Ag-Fe & 30 & 100 & 100 & 100 & 100 \\
\hline Ag-Fe & 400 & $>100$ & $>100$ & $>100$ & $>100$ \\
\hline Ag-Fe-Ni & 30 & $>100$ & $>100$ & $>100$ & $>100$ \\
\hline Ag-Fe-Ni & 400 & $>100$ & $>100$ & $>100$ & $>100$ \\
\hline
\end{tabular}


Table 6

Minimum inhibitory concentration (MIC50) of the synthesized silver nanoparticles accompanied different impurities against Bacteria

\begin{tabular}{|c|c|c|c|c|c|}
\hline \multirow[t]{2}{*}{ Compounds } & \multirow{2}{*}{$\begin{array}{l}\text { Temp. of } \\
\text { synthesis } \\
\text { खC }\end{array}$} & \multicolumn{2}{|c|}{ Gram + ve Bacteria } & \multicolumn{2}{|c|}{ Gram -ve Bacteria } \\
\hline & & $\begin{array}{l}\text { Staphylococcus } \\
\text { aureus }\end{array}$ & $\begin{array}{l}\text { Streptococcus } \\
\text { pyogenes }\end{array}$ & $\begin{array}{l}\text { Proteus } \\
\text { mirabilis }\end{array}$ & $\begin{array}{l}\text { Pseudomonas } \\
\text { aeruginosa }\end{array}$ \\
\hline $\begin{array}{l}\text { Ampicillin } \\
\text { (Control) }\end{array}$ & - & 25 & 25 & 25 & 25 \\
\hline Ag-D-C & 30 & 100 & 100 & 100 & 100 \\
\hline$A g-D$ & 400 & 50 & 50 & 100 & 100 \\
\hline $\mathrm{Ag}-\mathrm{Fe}$ & 30 & $>100$ & $>100$ & $>100$ & $>100$ \\
\hline $\mathrm{Ag}-\mathrm{Fe}$ & 400 & $>100$ & $>100$ & $>100$ & $>100$ \\
\hline $\mathrm{Ag}-\mathrm{Fe}-\mathrm{Ni}$ & 30 & $>100$ & $>100$ & $>100$ & $>100$ \\
\hline $\mathrm{Ag}-\mathrm{Fe}-\mathrm{Ni}$ & 400 & $>100$ & $>100$ & $>100$ & $>100$ \\
\hline
\end{tabular}

Table 7

Values of Crystallite size from X-ray analysis (XRD), particle size estimated from field emission scanning electron microscopy (FESEM) and particle size estimated from atomic force microscopy (AFM) of the synthesized silver nanoparticles accompanied different impurities

\begin{tabular}{|llllll|}
\hline Compounds & $\begin{array}{l}\text { Temp. of } \\
\text { synthesis } \\
\text { QC }\end{array}$ & $\begin{array}{l}\text { Crystallite size from } \\
\text { XRD }(\mathrm{nm})\end{array}$ & $\begin{array}{l}\text { Particle size obtained } \\
\text { from FESEM }(\mathrm{nm})\end{array}$ & $\begin{array}{l}\text { Particle size obtained } \\
\text { from AFM(nm) }\end{array}$ & References \\
\hline Ag-D-C & 30 & 85.4 & 110.2 & - & 39 \\
\hline Ag-D & 400 & 88.9 & 112.3 & - & 39 \\
\hline Ag-Fe & 400 & 42.5 & 116.4 & 107.76 & 38 \\
\hline Ag-Fe-Ni & 400 & 31.4 & 137.8 & 139.09 & 38 \\
\hline
\end{tabular}

Figures 


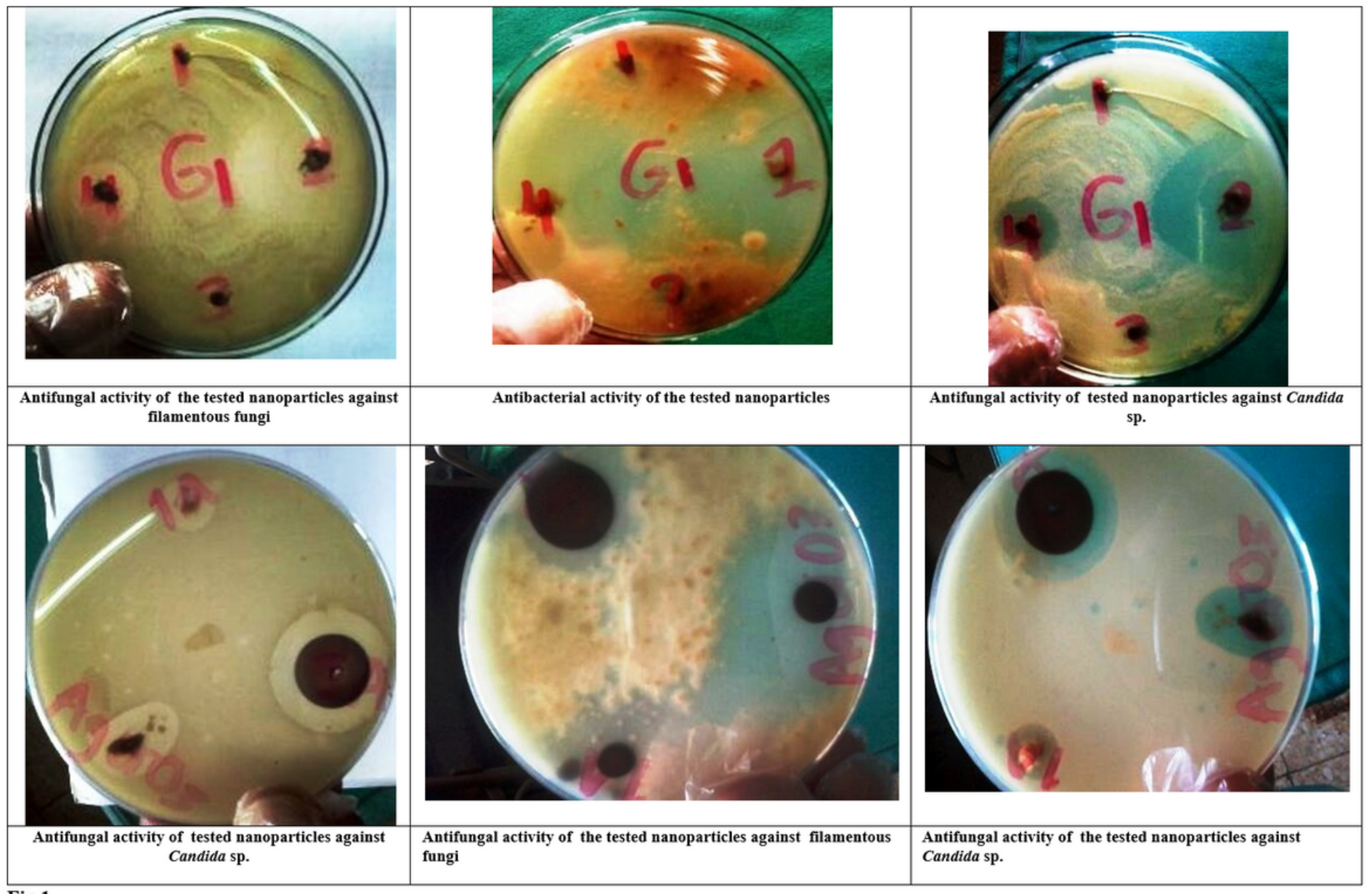

Fig.1

\section{Figure 1}

Representative photos showing the antimicrobial activity of the tested nanoparticles against opportunistic microorganisms 